\title{
ETYCZNY WYMIAR SZTUKI SVENA NORDQVISTA
}

\author{
KATARZYNA SMYCZYŃSKA ${ }^{1}$ \\ (Uniwersytet Kazimierza Wielkiego w Bydgoszczy)
}
Słowa kluczowe: dzieciństwo, dorosłość, etyczny wymiar ilustracji, humor wizualny, ironia, współczucie Key words: childhood, adulthood, ethical message in illustrations, visual humour, irony, compassion

\begin{abstract}
Abstrakt: Katarzyna Smyczyńska, ETYCZNY WYMIAR SZTUKI SVENA NORDQVISTA. „PORÓWNANIA" 19, 2016. T. XIX. S. 209-222. ISSN 1733-165X. Artykuł jest poświęcony analizie relacji bohaterów w serii książek o Pettsonie i Findusie. Przedstawia wizualną charakterystykę postaci między innymi w kontekście przestrzeni domu i otaczającej przyrody. Ilustracje Nordqvista dekonstruują powszechne wyobrażenia na temat dzieciństwa i dorosłości, ironicznie obnażając podporządkowanie konwenansom i wagę hierarchicznego porządku świata. Jest to ponadto wizja postawy współczującej, otwartej na inność. Sztuka Nordqvista kontynuuje pod tym względem myśl filozoficzną zawartą w pismach Janusza Korczaka.
\end{abstract}

\begin{abstract}
Katarzyna Smyczyńska, ETHICS IN THE VISUAL ART OF SVEN NORDQVIST. "PORÓWNANIA" 19, 2016. Vol. XIX. P. 209-222. ISSN 1733-165X. The article „Ethical gaze: the visual art of Sven Nordqvist" discusses the relationship between the two characters in the artist's Festus and Mercury books and the narrative role played in this context by the space in which they live. Nordqvist's illustrations deconstruct common notions of childhood and adulthood and ironically expose conventionality and hierarchical order often accepted unquestioningly by adults. The artist's characterisation of the protagonists puts special emphasis on their compassionateattitude and concern for the other. Nordqvist's visual art thus becomes a continuation of Janusz Korczak's educational philosophy.
\end{abstract}

Sztuka naiwna i sztuka dziecka stały się nieustającym źródłem mojej roboty graficznej i teatralnej. [...] Właśnie matka i ciotka ocaliły od zapomnienia wartości dzieciństwa. Nauczyły mnie spraw w sztuce najważniejszych [...]: bezpośredniości, radości i decyzji wyboru. Adam Kilian, „Teatr Lalek”

1 E-mail: ks@ukw.edu.pl 
Szwedzki twórca Sven Nordqvist jest obecnie jednym z najpopularniejszych ilustratorów i autorów książek dla dzieci w swoim rodzinnym kraju. Artysta, laureat szwedzkiej nagrody literackiej Augustpriset w kategorii książek dla dzieci oraz niemieckiej nagrody Deutscher Jugendliteraturpreis, zilustrował między innymi dobrze znane w Polsce opowiadania o Mamie Mu autorstwa Jujji i Tomasa Wieslander. Międzynarodową popularność zawdzięcza przede wszystkim serii autorskich książek o parze przyjaciól, staruszku i kocie, z których pierwsza została opublikowana w Szwecji w latach osiemdziesiątych. Od tego czasu książki przetłumaczono na kilkadziesiąt języków. Wykreowani przez Nordqvista bohaterowie, Pettson i Findus, w większości tłumaczonych wersji opowieści zachowali oryginalne imiona, choć w amerykańskim wydaniu opublikowanym przez Carolrhoda Books są znanijako Festus i Mercury. W ostatnich latach na kanwie książek Nordqvista powstały animacje, gry komputerowe, szwedzko-niemiecki serial animowany (emitowany także w Polsce w TVP1), a w 2014 roku również niemiecki film animowany z udziałem aktorów.

W bogato ilustrowanych opowieściach o żyjącym na wsi staruszku Pettsonie i jego mówiącym kocie Findusie humorystycznie przedstawiona codzienność gospodarstwa z wszędobylskimi kurami i zagraconym składzikiem na narzędzia okazuje się przy uważnym oglądzie wielowarstwową, metaforyczną opowieścią wizualną. Artyście udało się stworzyć coś niebywałego - wykreował na wpół nierzeczywisty, a jednak swojski, gościnny świat, dzieło, w którym tekst i obraz tworzą harmonijną całość, budują podszytą ironicznym dystansem wizję rzeczywistości i filozofię życia.

Forma opowieści wizualnych Nordqvista, o której będzie mowa w artykule, jest niepowtarzalna, podobnie jak klimat świata powstałego w wyobraźni artysty. Jeśli rozważać tę propozycję artystyczną szerzej i uznać ją za nośnik wartości i przesłanie etyczne, blisko jej z pewnością do wizji człowieka zawartej w pismach pedagogicznych autorstwa Janusza Korczaka. Jako fundamentalne elementy myśli Korczaka, przywołane tutaj na podstawie dwóch zbiorów: Jak kochać dziecko. Dziecko w rodzinie (Korczak 1958 [1919]) oraz Prawo dziecka do szacunku (Korczak 1958 [1929]), można z pewnością traktować szacunek wobec dziecka połączony z pełnym uznaniem jego podmiotowości, zrozumienie dla różnorodności ludzkich predyspozycji, temperamentów, dążeń, marzeń, wreszcie - pełne zaangażowania współczucie dla innego człowieka. Korczak pisze: „nie ma niedojrzałego [...], żadnej hierarchii wieku, żadnych wyższych i niższych rang bólu i radości, nadziei i zawodów" (Korczak 1958 [1929]: 19). Opartą na takim przekonaniu wizję człowieczeństwa można odnaleźć w tekstach i obrazach Nordqvista, a zwłaszcza w portrecie przyjaźni Pettsona i Findusa. Główne postaci uosabiają szczególny typ emocjonalnej relacji, w której partnerstwo, szacunek, radość życia oraz rozumna, troskliwa miłość konkretyzują się w oryginalny sposób na ilustracjach.

Wielowymiarowość opowieści o Pettsonie i Findusie nie przełożyła się dotąd na liczbę poświęconych im publikacji naukowych. Tymczasem ilustracje mają 
ogromny potencjał narracyjny, kondensują wiele środków wyrazu, zaś artysta finezyjnie łączy prostotę przekazu z wyrafinowaniem formy. Jak w prekursorskiej analizie dokonań szwedzkiego twórcy dowodzi Magdalena Sikorska, Nordqvist jest kontynuatorem średniowiecznych i renesansowych wizualnych tradycji narracyjnych, mających niejednokrotnie wymiar symboliczny lub alegoryczny. Autorka pokazuje, w jaki sposób te tradycje uaktualniają się w omawianych książkach we współczesnej, (post)modernistycznej odsłonie; analizuje między innymi metaforyczny potencjał szczegółu i koloru, zabieg wplatania pobocznych narracji wizualnych do głównej opowieści i współistnienie na ilustracjach elementów realistycznych i fantastycznych (Sikorska 2008: 52-63).

W recenzjach wydawniczych prac Nordqvista nieczęsto wzmiankuje się o możliwości pogłębionego odczytania jego książek; niektóre komentarze mówią najwyżej o atrakcyjności serii dla dorosłych czytelników. Wśród nich są na przykład spostrzeżenia Laury A. Wideburg, która za walory opowieści uznaje idylliczną aurę i poczucie wspólnoty w wykreowanym przez Nordqvista świecie, milczy jednak na temat dużej dawki ironii i absurdu, dekonstruujących sielskość pastelowych ilustracji (Wideburg). Z większości recenzji wynika, że to doskonała lektura przede wszystkim dla dzieci przedszkolnych i wczesnoszkolnych.

\section{Adresat}

Założenia na temat docelowego adresata książek Nordqvista można wytłumaczyć szeregiem czynników: na taką ocenę wpływają między innymi tytuły książek, ich format, specyfika ilustracji, bohater zwierzęcy, długość opowieści, a wreszcie ich tematyka (a raczej powierzchownie odczytywana fabuła). Twórca, pytany o to, na ile pracochłonny jest $\mathrm{w}$ jego wypadku proces tworzenia, mówi, że za odpowiedź może posłużyć liczba książek w serii - powstało ich zaledwie osiem w ciągu trzech dekad (Nordqvist, źródło elektroniczne). Przypisywana książkom aura „zabawności", niepozorność i peryferyjność świata, w którym ekscentryczny staruszek ugania się za kurami, obsiewa pole i chodzi na ryby z nieustannie skaczącym kotem, to tak naprawdę sprytny kamuflaż. Posługując się humorem wizualnym, pieczołowicie dopracowując szczegóły, artysta spaja lekkość formy z filozoficzną głębią treści. To, czego nie mówi się wprost, w tekście, dopowiadają ilustracje, które są przykładem mistrzowskiego operowania detalem, perspektywą i techniką malarską.

Książki o Pettsonie i Findusie, podobnie jak inne dzieła literatury skandynawskiej, bez wątpienia mają wśród swoich adresatów osoby w różnym wieku choćby z tego powodu, że z racji swej długości i formatu świetnie nadają się do wspólnej lektury, wspólnego odnajdywania coraz to nowych szczegółów na ilustracjach. Przy pomocy oszczędnego, bezpośredniego stylu tekstu autor celnie portretuje charakter relacji dziecka i towarzysza-opiekuna, gdzie bliskość emocjonalna wynika ze 
współdzielenia czasu, drobnych rytuałów i przestrzeni życia. Jednak to zapewne ilustracje stanowią największy walor opowieści, zapraszając zarówno młodszych, jak i starszych odbiorców do gościnnej krainy zabawy wizualnej. Ilustracje obfitują w zaskakujące zwroty akcji i zadziwiają obecnością elementów świata przedstawionego, które przeczą prawom fizyki i prawdopodobieństwa. W tym wypadku postmodernistyczne odrzucenie mimetyzmu nie jest tylko zabiegiem formalnym służącym urozmaiceniu lektury. Przeciwnie - zabawa formą stanowi niezbędną część narracji i charakterystyki stworzonego w opowieści świata „na opak”.

Z dużą dozą ostrożności (przy pełnym uznaniu doniosłości spostrzeżeń badacz$\mathrm{ki}^{2}$ ) posługuję się $\mathrm{w}$ odniesieniu do twórczości Nordqvista terminem „dwuadresowość", analizowanym przez Barbarę Wall ${ }^{3}$ w jego dwóch znaczeniach („dual” i „double”). Okazuje się, że granica między „dziecięcością" i „dorosłością” implikowanego czytelnika w niektórych dziełach literackich bywa nieostra; możliwości interpretacyjne i stopień dojrzałości emocjonalnej młodszych odbiorców to także kwestie trudno rozstrzygalne. Analizowanym książkom bliżej do kategorii „dual”, ponieważ nic nie wskazuje na to, że ironia, którą posługuje się artysta, jest konspiracyjnym gestem narratora, czynionym „ponad głową dziecięcego czytelnika”. Ironiczne podteksty ilustracji pozostają, ze względu na wpisany w nie humor, otwarte i czytelne dla odbiorców w różnym wieku. Ponadto książki pozwalają na identyfikację z bohaterem bliższym im wiekiem i doświadczeniem, zarazem umożliwiając ponadpokoleniowe porozumienie i tworząc przestrzeń dla empatycznego odczytu.

Książki o Pettsonie i Findusie wpisują się w szerszy trend w literaturze współczesnej, w którym granice między literaturą dla dziecka i literaturą dla dorosłego zostają rozmyte, choć nie traci się przy tym z pola widzenia najmłodszego odbiorcy. Cykl zachowuje wszystkie istotne cechy literatury dziecięcej, nazwanej przez Jerzego Cieślikowskiego umownie „czwartą” lub „osobną” (Cieślikowski 1985), a jednak tę "osobność" przełamują. Zofia Adamczykowa pisze, że cechą wielu współczesnych utworów mieszczących się w obrębie "czwartej” literatury jest brak „,wyraźnego adresu czytelniczego”, po czym dodaje rzecz znamienną: ,[z]jawisko d wuad resow ości, czy nawet wi el oadresow ości, z całą pewnością dotyczy arcydzieł literatury dziecięcej, które można odczytywać w różnych przestrzeniach i czasach na wielu poziomach interpretacyjnych [wyróżn. - Z.A.]" (Adamczykowa 18). Uniwersalizacja adresata nie musi oznaczać, że literatura jest wybitna, ale tak właśnie rzecz ma się w przypadku książek Nordqvista. Są one

2 Zob. np. dyskusję naukowców na ten temat (Beckett).

$3 \mathrm{~W}$ prekursorskiej książce dotyczącej typów narracji w literaturze dziecięcej Wall wyróżniła kategorię pojedynczego adresata („single address") oraz dwie formy dwuadresowości: „double" i „dual”. Analizując pierwszy typ dwuadresowości, Wall odwołuje się do eseju Michaela Egana na temat twórczości Jamesa Barriego. W tekście adresowanym do dzieci Barrie zawiera treści „ponad ich głowami”, które są formą „puszczania oka” do dorosłych odbiorców. Wall definiuje dwuadresowość typu „dual” jako połączenie („fusion”) obu wcześniej wymienionych typów: narracja jest skierowana do dzieci, jednocześnie pozostając satysfakcjonująca dla dorosłych (Wall 21, 35-36). 
spełnieniem pewnego ideału sztuki, o którym w jednej z audycji Jarosław Kilian mówi w kontekście działalności swego ojca, Adama: „to jest poszukiwanie ideału twórczości: a ideał twórczości to jest sztuka dostępna dla dziecka, jak i dla profesora uniwersytetu. To jest twórczość, która zachwyca i porywa i maluczkich, i wykształconych, i wielkich" (Kilian).

\section{Zbliżanie horyzontów}

Zarówno tekst, jak i ilustracje można uznać za specyficzną wykładnię ponadpokoleniowej pedagogiki, która przewartościowuje myślenie o istocie życia i priorytetach życiowych. Książki Nordqvista redefiniują pojęcie emocjonalnej dojrzałości dzieci i dorosłych; kontestują w ten sposób powszechne wyobrażenia współczesnej kultury zachodniej o dzieciństwie, dorosłości i starości. To kot odzwierciedla ideę dzieciństwa, ale nie da się bliżej określić jego wieku i wyznaczyć ram dzieciństwa. Osoba staruszka - na pierwszy rzut oka prostolinijnego towarzysza zabaw, w rzeczywistości zaś uważnego opiekuna - reprezentuje podobnie nieokreśloną ideę dorosłości. Mimo oczywistych, zdawałoby się, wizualnych atrybutów zaawansowanego wieku Pettson uosabia dojrzałość w szerokim rozumieniu: może być identyfikowany z rodzicem dorastającego dziecka, czyli często osobą w średnim wieku, ale może być także przekonującą metaforą starszego rodzeństwa.

Z pewnością sympatia implikowanego narratora jest po stronie dziecięcego oglądu świata. Sugerują to wpisane w ilustracje elementy sztuki naiwnej (zob. Sikorska 57) i humor wizualny, a także wątki fabularne: pragnienie przeżycia przygody i spontaniczność bohaterów. Każde błahe z punktu widzenia dorosłych doświadczenie nabiera wartości dzięki odzwierciedlonemu na ilustracjach zaangażowaniu emocjonalnemu Findusa i obecności fikcyjnych elementów, ożywiających pozorną monotonię gospodarstwa. Książki nieodmiennie kończą się symbolicznym powrotem Findusa do domu, wspólną rozmową przy kawie lub sceną schronienia w ramionach opiekuna. Mają więc cechy charakterystyczne dla literatury dla najmłodszych: są zbudowane w oparciu o dialog między bohaterem o cechach dziecka a dorosłym przewodnikiem, zaś dydaktyzm (choć w tym wypadku bardziej zasadne jest mówienie o wizji etycznej) ma formę pośrednią, ukrywa się za ludycznością, fantastyką, przygodą oraz komizmem (por. Adamczykowa 32-33). Mimo to powracającym, nie zawsze bezpośrednio, tematem jest także dorosłość, starość, inność, a ilustracje współbudują symboliczną przestrzeń pozwalającą zrozumieć stany będące częścią doświadczenia innych istot.

Ilustracje w serii o staruszku i kocie w ich wymiarze symbolicznym i emocjonalnym mogą być rozumiane przede wszystkim jako opowieści o przeżyciach, o budowaniu i pogłębianiu więzi. Artysta tworzy przestrzeń dla czytania wspólnotowego między innymi poprzez wizualną charakterystykę bohaterów i otaczającego ich 
świata. W rysunkach dominuje zasada komicznego podobieństwa, wyrażanego na przykład w nieco karykaturalnej postawie ciała, ubiorze (pasiaste spodnie-ogrodniczki Findusa przypominają wzorem koszule Pettsona). Wiele obrazków charakteryzuje obie postaci oraz ich otoczenie, wykorzystując znaną $\mathrm{w}$ naturze strategię mimikry. Pettson i Findus (a czasem i towarzyszące im rośliny, miniaturowe stworzenia) jakby bezwiednie obierają podobną postawę, czynią te same gesty, patrzą w tym samym kierunku. Przyroda pełni funkcję alter ego bohaterów, intensyfikuje odczuwane przez nich emocje - przykładowo kwiaty więdną, gdy Pettson jest przygnębiony. Wszystkie elementy tego mikroświata, także te teoretycznie nieożywione (krzesła, obrazy itp.), przejmują od siebie nawzajem pewne właściwości czy stany emocjonalne, na swój sposób reagują na aktualną sytuację bohaterów.

\section{Ironiczny dystans}

Nordqvist igra z dwoma niezwykle silnymi stereotypami - infantylizowania dzieciństwa i starości. Mimo że dwie główne postaci to mówiący kot w spodniach i szalony staruszek realizujący z entuzjazmem jego pomysły, mimo że obaj bohaterowie noszą nieprzydające im gracji pasiaste, workowate ubrania, przyjmują śmieszne pozy, a ich mowa ciała bywa karykaturalnie ekspresyjna, czujemy do nich sympatię i widzimy w nich autentyzm człowieczeństwa, odczytujemy ich bliskość emocjonalną i zasługującą na wyjątkowy szacunek przyzwoitość. Komizm bohaterów Nordqvista przypomina typ bohatera wykreowanego przez Charliego Chaplina wraz z jego duchowym przesłaniem.

Z przekonaniem można nazwać Nordqvista cichym prowokatorem, który wrysowuje w zwodniczo sielankowe ilustracje rewolucyjną wizję dzieciństwa i dorosłości. W ten sposób wpisuje się w humanistyczną filozofię Korczaka, krytyczną wobec sztywnych podziałów i hierarchii związanych z wiekiem. Mowa ciała Findusa - aktywność, spontaniczne gesty i radosna pewność siebie - podkreśla znaczenie dzieciństwa niehamowanego nakazami i zakazami. Ten bohater jest nieodmiennie aktywnym uczestnikiem wydarzeń, partnerem Pettsona $\mathrm{w}$ powierzonych mu zadaniach. Wizja dorosłości jest zdekonstruowana w podobny sposób, zaś zabawa wizualna polegająca na żonglowaniu stereotypem odbywa się na wielu poziomach. Pettson jest portretowany w absurdalnych, czasem teoretycznie nieco kompromitujących sytuacjach: widzimy go ubrudzonego surowymi jajkami, ubranego jedynie w kalesony, gdy pierze swoją jedyną parę spodni, lub wystrojonego $\mathrm{w}$ falbaniasty damski fartuszek, gdy zamierza upiec tort dla Findusa. Powaga przypisana dorosłości jest dyskretnie, acz skutecznie kontestowana - na przykład na ilustracji, gdzie miniaturowa zabawka na kółkach, przypuszczalnie należąca do Findusa, ma postać Pettsona. $Z$ tekstu można się zresztą dowiedzieć, że Pettsonowi na powadze (a co za tym idzie na statusie, opinii itd.) w ogóle nie zależy. 
Igranie z zastanym, hierarchicznym, kojarzonym ze światem dorosłych porządkiem odbywa się na poziomie ilustracji także poprzez karnawalizację świata przedstawionego. Rysunki są przesiąknięte atmosferą zabawy i wyśmiewają przywiązanie do porządku i banalnej konwencjonalności. Krowa na obrazku wiszącym w pokoju Pettsona ma ogromne wymiona, a przedmioty wypełniające dom pełnią najdziwniejsze funkcje, ponieważ bohaterowie kreatywnie wykorzystują to, co mają pod ręką. Obrazy przyrody czy też szerzej - świata ożywionego, które wypełniają karty książek, nadają mu specjalny status. Okazuje się, że tajemnicze miniaturowe postaci zaludniające domostwo i ogród niczym powieściowi Pożyczalscy pozostają w symbiotycznej, równościowej relacji z większymi domownikami. Czasem uczestniczą w wydarzeniach, czasem są ich zainteresowanymi, choć milczącymi świadkami, czasem zaś ich obecność buduje ironiczny dystans wobec kłopotów Pettsona i Findusa. W tym świecie można dostrzec obejmującą się parę zakochanych czy nieszczęśliwców, uciekających w pośpiechu ze swoim dobytkiem z powodu hałasu, jaki robi kogut. Ilustracja, na której maleńkie zwierzęta kupują bilety, by nacieszyć wzrok spektaklem z życia Pettsona i Findusa, przypomina o fikcyjności opowieści, ale i wprowadza dystans wobec hierarchii wpisanej w dychotomię mały - duży (dorosły, ważny).

Wizualna opowieść Nordqvista jest w pewnej mierze ironicznym komentarzem do stanu współczesnej kultury, szczególnie w jej wielkomiejskim, konsumpcyjnym wymiarze, choć taki rodzaj interpretacji nie oddaje ponadczasowej wartości tych książek. Centrum świata są tu peryferie, gdzie życie płynie (nie biegnie!) $\mathrm{w}$ innym tempie. Wartości, którym bezkrytycznie hołduje się niekiedy w świecie dorosłych (o czym pisze Korczak w kontekście narzucania sztywnych konwenansów dzieciom), są podobnie zdefamiliaryzowane. Pettson i Findus ujmują swoją obojętnością wobec szeroko pojmowanego dyktatu robienia tzw. „dobrego wrażenia", ponieważ pośrednio lub wprost obnażają dulszczyznę wykraczającą poza konkretny czas i miejsce. Kury Pettsona, traktowane z pobłażliwością ze względu na ich „nierozgarnięcie”, mają na ilustracjach znamiona parodii mieszczańskości: paradują wystrojone $\mathrm{w}$ biżuterię, piją kawę $\mathrm{z}$ filiżanek i zasiadają $\mathrm{w}$ fotelach. Z drugiej strony każdy ma tu prawo do pewnych słabostek, a naturalnym elementem wzajemnych relacji jest pozbawiona uprzedzeń życzliwość.

Jeśli uznać, że dom to w jakimś sensie „przedłużenie”, psychologiczny portret, eksternalizacja tożsamości człowieka, to dom Pettsona i Findusa charakteryzuje te postaci w pełni: jest wielkim, ożywionym, gościnnym organizmem. Wszędzie panuje przytulny rozgardiasz, przedmioty znajdują tu, jak już wspomniałam, nietypowe zastosowanie lub mają niekonwencjonalne proporcje. Rysunki na ścianach zmieniają zawartość w zależności od nastroju gospodarza, zaś ulubiony motyw na obrazach (które są w odbiorze społecznym świadectwem gustu i aspiracji domowników) to krowa. Ironiczne, zdystansowane spojrzenie umacniają zastosowane przez Nordqvista techniki malarstwa iluzjonistycznego, w tym zabieg znany jako tromp d'oeil. 
Realizm fabuły jest dekonstruowany poprzez umieszczenie części akcji w obrazie stojącym tuż przy bohaterach. Ten nieco absurdalny, odrealniony mikrokosmos uwrażliwia, każe być czujnym wobec zastanych reguł, uczy stoickiego dystansu do świata, manifestuje wolność od konieczności dostosowania się do arbitralnie narzucanych konwencji.

\section{Przestrzeń etyczna}

Poczynione dotychczas uwagi prowadzą do wniosku, że o uniwersalnej wartości książek Nordqvista stanowi ich oryginalna forma oraz wpisana w nią refleksja etyczna. Ilustracje wykorzystują potencjał wieloadresowości, stanowią przykład sztuki ponadpokoleniowej, ale i ponadczasowej, która mówi o potrzebie zrozumienia Innego i o roli bliskości emocjonalnej. Zapewne nieprzypadkowo Nordqvist wybrał dla Pettsona i Findusa stary, wiejski dom bez nowoczesnych wygód, obok którego stoi szopa $z$ narzędziami i drewutnia. $W$ takim otoczeniu bohaterowie mogą skupić się na budowaniu pogłębionej relacji i uczą się dostrzegać potrzeby innych żywych istot. Są bogaci w doświadczenia, które stają się coraz bardziej obce współczesnym mieszkańcom miast. Architekt Juhani Pallasmaa podkreśla, że w zindustrializowanej, zmechanizowanej, materialistycznej kulturze konsumpcyjnej mamy mniej możliwości sensorycznego kontaktu z pracą i produkcją rzeczy, a także ze zmiennością naturalnych zjawisk. To bliskie więzi rodzinne i społeczne, kontakt ze zwierzętami, zintegrowanie psychicznych i fizycznych aspektów życia zwiększa szansę wykształcenia empatii, kształtuje postawę etyczną (zob. Pallasmaa 12).

W refleksji nad znaczeniem etycznym książek Nordqvista i ich pokrewieństwa duchowego z filozofią Korczaka ważne wydaje się przywołanie kategorii współczucia. W książce dotyczącej znaczenia emocji w kształtowaniu myślenia etycznego Martha C. Nussbaum definiuje współczucie jako zespół bolesnych odczuć wywołanych świadomością niezasłużonego cierpienia innej osoby. Rozwija tę definicję w oparciu o trzy elementy kognitywne współczucia wyróżnione przez Arystotelesa w Retoryce: przekonanie o intensywności nieszczęścia oraz o tym, że los, który spotkał tę osobę, jest niezasłużony, a także założenie możliwości dzielenia losu tej osoby (por. Nussbaum 301, 306). Wśród prawdopodobnych nieszczęść Arystoteles widział między innymi starość, śmierć, słabość fizyczną i brak nadziei na polepszenie losu. Był przekonany, że ocena powagi sytuacji musi być dokonana z perspektywy osoby, którą spotkał ten los, gdyż punkt widzenia osoby współczującej może być inny. Istotnym elementem w odczuwaniu współczucia jest przekonanie, że niesprawiedliwość, która dotyka kogoś dobrego, wydarza się poza kontrolą tej osoby. Trzecim czynnikiem jest świadomość własnej słabości połączona z obawą o przyszłość. Nussbaum polemizuje tu z Arystotelesem, uznając, że strach przed 
podobnym losem nie musi być warunkiem kształtującym współczucie wobec Innego (por. Nussbaum 309, 312, 324).

Mimo że autorzy analizujący emocjonalne i etyczne aspekty ilustracji w literaturze dla dzieci często posługują się terminem „empatia” (Cotton; Nikolajeva), Nussbaum różnicuje oba pojęcia i dowodzi, że empatia co prawda wiąże się ze współczuciem, ale $\mathrm{w}$ przeciwieństwie do niego ma charakter ograniczony, skończony i nie skłania do działania, choć może stanowić etap pośredni - drogę do współczucia (Nussbaum 331-332). Można być empatycznym w stosunku do osoby pokrzywdzonej i jednocześnie nie oceniać jej położenia jako godnego pożałowania; co więcej, osoba empatyczna teoretycznie może nawet czerpać przyjemność z nieszczęśliwego położenia innego człowieka. Nussbaum przekonuje, że edukacja w zakresie kultury i specyfiki różnych kultur, a także obcowanie ze sztuką zaangażowaną, która nie stroni od tragicznych tematów, to właściwa droga do kultywowania współczucia i zrozumienia innych (Nussbaum 302, 432).

Nordqvist stosuje kilka strategii wizualnych, które kształtują postawę współczucia i pogłębiają zrozumienie trudnych doświadczeń bliskich osób, między innymi metaforyczne obrazowanie emocji, wyrażone za pomocą oryginalnych zabiegów formalnych. W opowieści Findus się wyprowadza osamotnienie Pettsona po wyprowadzce kota przedstawione jest za pomocą faktury obrazu - widzimy bohatera siedzącego przy stole zastawionym jedzeniem, tak jak zwykł siadać $w$ towarzystwie Findusa. Jedynym śladem po obecności kota jest jego wysokie krzesełko, teraz puste, i mała filiżanka, którą Pettson z przyzwyczajenia napełnił kawą. Faktura obrazka jest ziarnista, chropowata, przez co wywołuje wrażenie szorstkości, a zarazem sygnalizuje przygnębienie i marazm. Kiedy Findus zaczyna tęsknić za Pettsonem, ta sama faktura wypełnia przestrzeń jego małego domku (w opozycji do przejrzystego zewnętrza, z którego wygląda przez otwarte drzwi Pettson).

Klamrą spajającą całość jest scena, w której Findus jako pretekst powrotu do domu podaje strach przed lisami, a Pettson chętnie przyjmuje i akceptuje ten pretekst. W tej ważnej i intymnej chwili Nordqvist stosuje inną perspektywę: odbiorca nie jest już bezpośrednim świadkiem wydarzeń, może jedynie podglądać bohaterów przez okno. W środku jest jasno i przytulnie, zaś Pettson i Findus promienieją - dosłownie i metaforycznie - w cieple domowego ogniska. Na zewnątrz panuje mrok, pogłębiony przez zastosowaną po raz kolejny ziarnistą fakturę, w przestrzeni którego zanurzone są czatujące pod oknem, choć nieistniejące lisy. Ich obecność na ilustracji wydaje się konieczna, by zracjonalizować i uwiarygodnić powrót Findusa. To zabieg, dzięki któremu odsuwamy potrzebę racjonalności, gdyż, podobnie jak Pettson i Findus, utożsamiamy się z dziecięcą (a może raczej uniwersalną) tęsknotą za emocjonalną i fizyczną bliskością.

Kształtowanie współczującego spojrzenia umożliwia między innymi portretowanie zgodnego wspólistnienia $\mathrm{w}$ domostwie różniących się od siebie realnych i fikcyjnych istot, jak i znamienna bliskość ludzi, zwierząt i przyrody. Ta druga, 
postrzegana w wymiarze metaforycznym, symbolicznie łączy młodość i starość, otwiera na doświadczenie przemijania i inności. Na przykład książka Biedny Pettson rozpoczyna się przejmującą sceną odzwierciedlającą stan ducha Pettsona. Wyobrażenie jesieni w oczach artysty może być potraktowane wyłącznie jako pretekst do opowiedzenia historii o trudnym dniu. Ponieważ jednak mroczna, wywołująca apatię wizja jest obecna na większości ilustracji, można ją odczytać jako metaforyczne oddanie stanu psychiki i wieku staruszka. Zamierająca przyroda współgra z przygnębieniem Pettsona i uzupełnia ten metafizyczny kontekst. Dramatyczny początek, pokazujący rozbieżność doświadczeń obu bohaterów i związane z tym napięcie Pettsona oraz bezradność Findusa, dzięki gotowości do wsłuchania się w Innego prowadzi ku porozumieniu. Warto zauważyć, że to Findus, który współcierpi i z tego powodu wypróbowuje wszelkie znane mu sposoby, by poprawić towarzyszowi nastrój, przejmuje w opowieści rolę ratownika duchowego.

Nieobecne w tekście, a będące ważnymi elementami ilustracji drobne elementy domostwa - stare, pozornie nikomu już niepotrzebne - w rękach Pettsona otrzymują drugie życie. To nie tylko pochwała wyobraźni i kreatywności czy deklaracja sprzeciwu wobec konsumpcjonizmu współczesnego świata, ale także przesłanie etyczne dotyczące starości jako naturalnego elementu krajobrazu życia społecznego. Ponieważ te motywy zostały wtopione w tło ilustracji, można je uznać za rodzaj smutnego aspektu opowieści o starości, która staje się społecznie niewidzialna. Zaskakującą obecność wysuszonej choinki świątecznej z resztkami dekoracji wśród rozkwitającej wiosennej przyrody można interpretować jako wyraz stylu życia Pettsona i jego niefrasobliwości w kwestii porządków. Koncepcja książki każe jednak sądzić, że przyroda ma tu, podobnie jak na innych ilustracjach, wymiar metaforyczny, ukazuje z jednej strony naturalność przemijania, z drugiej zaś symbiotyczną relację młodych i starych pierwiastków świata, naturalne wspólistnienie tego, co za chwilę będzie tylko wspomnieniem, i radosnej, rozbuchanej energii tego, co dopiero się rozwija.

Humor wizualny pozwala opowiadać o starości ze współczuciem pozbawionym sentymentalizmu. W Polowaniu na lisa podeszły wiek Pettsona jest pokazany metonimicznie $\mathrm{w}$ postaci sterty okularów leżących w bezładzie na nocnej szafce; w opowieściach Rwetes w ogrodzie i Goście na Boże Narodzenie przy łóżku pojawia się z kolei sztuczna szczęka umieszczona w szklance. Szczęka jednocześnie jest i nie jest częścią ciała Pettsona (metaforycznie także jego tożsamości), jest tylko dodatkiem do niego, nie stanowi o nim jako takim. $Z$ drugiej strony ma ona pewne znamiona cech osobowości Pettsona, jej zantropomorfizowana wersja może nawet wzbudzać sympatię. Na ilustracji zawarto aluzyjną zabawę towarzyszącymi detalami: szczęka szczerzy zęby w stronę lampki udekorowanej figurkami ujadającego psa i przytrzymującego go na smyczy właściciela, przypominającego nieprzyjemnego sąsiada Pettsona. Straszność, obcość i wypieraną ze świadomości nieuchronność starości udaje się w ten sposób symbolicznie przeżyć, przepracować dzięki konwencji prze- 
śmiewczej. Dzięki absurdowi wpisanemu w kontekst ilustracji sztuczna szczęka paradoksalnie odrealnia starość, a zarazem ją uobecnia, ucieleśnia i materializuje, kształtując współczujące spojrzenie.

Wyobrażenie starości jako zmierzchu życia i okresu zasłuchiwania się w przeszłość, do której młodsi nie mają dostępu, choć są ważni jako wspierający swoją obecnością towarzysze, znajduje oryginalną wizualną konkretyzację w dwóch innych opowieściach. W książce zatytułowanej Pettson na biwaku stary namiot przypomina Pettsonowi o jego młodości i staje się pretekstem do wspólnej wyprawy nad jezioro. Kiedy bohaterowi udaje się nieoczekiwanie złowić i zaraz potem wypuścić ogromną rybę, wracają wspomnienia z dawnych lat. Ilustracje oddają trudno wyrażalne słowami zasłuchanie $\mathrm{w}$ siebie i przywoływanie $\mathrm{w}$ myślach własnej młodszej jaźni. Autor wykorzystuje przy tym szereg wizualnych środków narracyjnych: metaforyczny potencjał przestrzeni, perspektywy, operowanie dynamiką i barwą w obrazie.

Nagła zmiana nastroju Pettsona, bolesna świadomość przemijania wyrażona jest $\mathrm{w}$ fizycznej postawie, $\mathrm{w}$ jego zwróceniu się w kierunku jeziora, które zostawili za sobą. Bohater stoi plecami do czytelnika, nieobecny duchem, choć otoczony kipiącym wokół życiem, zapatrzony w to, co symbolicznie obrazuje jego przeszłość. Zgromadzone wokół niego postaci wyrażają gestami swoje podekscytowanie w wymiarze metaforycznym są esencją młodości, uosobieniem entuzjazmu i energii życiowej. Rozemocjonowany Findus ciągnie Pettsona za rękę w prawą stronę, „ku przyszłości", choć zwrócony w lewo Pettson opiera się, nie chcąc iść dalej. Jego postać stanowi kontrapunkt dla reszty otoczenia: w sposób symboliczny zatrzymał się on w świecie wspomnień, do którego nikt poza nim nie ma dostępu.

Na kolejnej ilustracji za pomocą perspektywy i techniki malarskiej oddano poczucie nieodwracalności przeszłości. Pettson i Findus, ukazani z oddalenia, siedzą o zmierzchu przy ognisku. Namalowany akwarelą krajobraz wokół nich sprawia wrażenie zamglonego, rozmytego. Ilustracja pokazuje ciszę, skupienie i smutek, a zarazem jest obrazem wspólnego czuwania i zamyślenia. Wieczorna kontemplacja umożliwia współdzielenie przeżywanej chwili. To moment, w którym Findus ma szansę wsłuchać się w odczucia Pettsona; symbolicznie wyobrażone przeczucia dotyczące przyszłości są udziałem obu bohaterów.

Jeśli przyjąć za Nussbaum, że współczucie wobec wybranych (np. bliskich) osób to rodzaj ograniczonej etyki („limited ethics”) (Nussbaum 336-337), a pełnię postawy etycznej osiąga się przez odczuwanie współczucia wobec wszystkich dotkniętych przez los i pogardzanych, to etyczny wymiar ilustracji Nordqvista być może najgłębiej wyraża się w książce Polowanie na lisa. Pettson i Findus przygotowują misterną pułapkę na krążące po okolicy zwierzę. Początkowo zdaje się, że robią to, by skutecznie odstraszyć lisa od gospodarstwa, ale okazuje się, że w ten sposób mogą go uratować przed strzelbą nieprzyjemnego sąsiada i zębami jego psa. 
Planowany przebieg akcji - a raczej jej zwizualizowana projekcja w umyśle podekscytowanego Findusa - jest wyobrażony na ilustracjach poprzez dynamikę postaci, świetlistość wyobrażającą wybuchy, a także dzięki skondensowaniu szczegółów w obrazie. Kiedy na podwórzu naprawdę pojawia się lis, kolorystyka, przestrzeń i perspektywa ulegają diametralnej zmianie. Lis nie zachowuje się zgodnie z przewidywaniami i ostatecznie nie dochodzi do wybuchu. Akcja nagle spowalnia wskutek decyzji artysty, by sportretować wymianę spojrzeń Pettsona i lisa. Dzięki temu atmosfera ekscytacji pierzchnie, zastąpiona - co pokazuje w sposób symboliczny wyobrażona scena - kontemplacją nad sytuacją zwierzęcia. Ilustracja jest ciemna, a czytelnik patrzy na lisa znad ramienia Pettsona, który podgląda zwierzę przez firankę. Kolejna ilustracja odwraca perspektywę: tylko tym razem spoglądamy na dom Pettsona z punktu widzenia oddalonego od gospodarstwa lisa.

Umożliwienie odbiorcy chwilowej identyfikacji ze spojrzeniem Innego diametralnie zmienia ogląd sytuacji, jednak już samo pojawienie się rzeczywistego lisa i jego spokojne zachowanie powoduje, że wciąż świeże wspomnienie planu polowania wydaje się groteskowe. Zmiana atmosfery poprzez zastosowaną $\mathrm{w}$ tej scenie zgaszoną kolorystykę (dominuje barwa ciemnoniebieska), zatrzymanie akcji, a wreszcie kluczowy moment spojrzenia na sytuację oczami domniemanego agresora rodzą współczucie wobec zwierzęcia, które - wbrew opowieściom sąsiada okazuje się chore, głodne i bezbronne. Inny, którego potencjalna bliskość wywołała obawę, w bezpośrednim spotkaniu zburzył wybudowaną wcześniej i, jak się okazało, irracjonalną wizję.

Wyobrażenia Findusa, które złożyły się na spójną opowieść z zaplanowanym przez niego zakończeniem, w tej jednej chwili musiały zostać zweryfikowane. Nordqvist pokazuje, jak łatwo zbudować przekonującą narrację we własnym umyśle, nie opierając się na bezpośrednim doświadczeniu, a także jak łatwo poddać się nieuzasadnionej niechęci wobec obcego i przypisać mu jednoznacznie wrogie zamiary. Obraz mówi więc o konieczności stałej refleksji w osądach moralnych oraz o tym, że współczucie jest miarą człowieczeństwa.

Książki Nordqvista są wyjątkowym przykładem kontestatorskiego oglądu rzeczywistości, ukrytego pod wizualną maską przedstawienia naiwnego. Kontestacja nie przeszkadza przy tym artyście z czułością portretować swoich bohaterów uosabiających żywą, troskliwą, otwartą postawę wobec świata ludzi i przyrody. Nordqvist mistrzowsko wykorzystuje komizm postaci i sytuacji; są to dla niego strategie posiadające moc inspirowania przemiany etycznej. Jest to konwencja, która czyni możliwym wyjście poza sferę familiarności oraz przyzwyczajenia i rozwija świa- 
domość. Twórczość Nordqvista pozwala ujrzeć świat na nowo. Przypomina to, co pisał Bogdan Dziemidok na temat roli komizmu w sztuce:

Nie ma śmiechu bez zdziwienia, a zdziwienia poza sferą poznawczą. Źródłem zdziwienia, a wtóre również śmiechu jest jakiś nagły pomysł, czyli pomyślenie czegoś w sposób nowy, spostrzeżenie czegoś nowego lub ujrzenie rzeczy znanej w nowym świetle, znalezienie nie zauważonego dotąd podobieństwa i nagłe skojarzenie w myśli i wyobraźni elementów rzeczywistych dotąd nie skojarzonych (Dziemidok 131).

Autor książek o Pettsonie i Findusie stwarza idealne warunki do aktywnego czytania ilustracji: cały skomplikowany organizm, jakim jest gospodarstwo Pettsona, żyje tu własnym, zaskakująco bogatym życiem. Te wizualne opowieści inicjują twórcze myślenie, a ponadto poprzez swoich bohaterów zapraszają, by dojrzewać emocjonalnie, pozostając dziecięco otwartym na świat. Zdziwienie czytelnika, a co za tym idzie - myślenie, o którym pisze Dziemidok, Nordqvist wywołuje, wykorzystując precyzyjnie dobrane techniki opowiadania obrazem o emocjach i doświadczeniach, które niejednokrotnie trudno ująć w słowa. Świeżość i swoista dziecięcość spojrzenia to umiejętność zobaczenia świata oczami Innego, czytanie ponad pewnymi supozycjami - wnikliwe, czujne, życzliwe i troskliwe. Kiedyś takiego spojrzenia uczył Janusz Korczak, dziś w taki właśnie sposób uczy patrzeć Nordqvist.

\section{BIBLIOGRAFIA}

\section{Literatura podmiotu}

Nordvist, Sven. Biedny Pettson. Przeł. Barbara Hołderna. Poznań: Media Rodzina, 2009.

Nordqvist, Sven. Findus się wyprowadza. Przeł. Magdalena Landowska. Poznań: Media Rodzina, 2013.

Nordqvist, Sven. Goście na Boże Narodzenie. Przeł. Barbara Hołderna. Poznań: Media Rodzina, 2008.

Nordqvist, Sven. Kiedy mały Findus się zgubit. Przeł. Barbara Hołderna. Poznań: Media Rodzina, 2006.

Nordvist, Sven. Pettson na biwaku. Przeł. Barbara Hołderna. Poznań: Media Rodzina, 2013.

Nordvist, Sven. Polowanie na lisa. Przeł. Barbara Hołderna. Poznań: Media Rodzina, 2007.

Nordqvist, Sven. Rwetes w ogrodzie. Przeł. Barbara Hołderna. Poznań: Media Rodzina, 2007.

Nordqvist, Sven. Tort urodzinowy. Przeł. Barbara Hołderna. Poznań: Media Rodzina, 2006.

\section{Literatura przedmiotu}

Adamczykowa, Zofia. „Literatura «czwarta» - w kręgu zagadnień teoretycznych”. Literatura dla dzieci i młodzieży (po roku 1980). Red. K. Heska-Kwaśniewicz. Katowice: Wydawnictwo Uniwersytetu Śląskiego, 2008. S. 13-43.

Beckett Sandra L., red. Transcending Boundaries: Writing for a Dual Audience of Children and Adults. London \& New York: Garland, 1999.

Cieślikowski, Jerzy. Literatura osobna. Oprac. R. Waksmund. Warszawa: Nasza Księgarnia, 1985. 
Cotton, Penni. „Old Age and Death in Northern European Picture Books: Achieving Empathy through Textual and Filmic Images of Sweden's Kan du Vissla Johanna". Global Perspectives on Death in Children's Literature. Red. L.D. Clement, L. Jamali. New York \& London: Routledge, 2016. S. 161-176. Dziemidok, Bogdan. O komizmie. Warszawa: Książka i Wiedza, 1967.

Kilian, Jarosław. „Jacek, Agatka i inne lalki. Opowieść o sztuce teatralnej Adama Kiliana”. Audycja „Notatnik Dwójki”. Prowadzenie: Aldona Łaniewska-Wołk. Emisja: 01.12.2015. Web. 10.12.2015. <http://www.polskieradio.pl/8/1594/Artykul/1551960/>

Korczak, Janusz. Jak kochać dziecko. Dziecko w rodzinie. Warszawa: Państwowe Zakłady Wydawnictw Szkolnych, 1958 [1919].

Korczak, Janusz. Prawo dziecka do szacunku. Warszawa: Państwowe Zakłady Wydawnictw Szkolnych, 1958 [1929].

Nikolajeva, Maria. „«The Penguin Looked Sad»: Picturebooks, Empathy and Theory of Mind”. Picturebooks: Representation and Narration. Red. B. Kümmerling-Meibauer. New York: Routledge, 2014. S. 121-138.

Nordqvist, Sven. „Findus... a może raczej Pettson”. Web. 20.02.2015<http:/ / pozarozkladem.blogspot. com/2013/06/findus-moze-raczej-pettson.html>

Nussbaum, Martha C. Upheavals of Thought: The Intelligence of Emotions. Cambridge: Cambridge University Press, 2001.

Pallasmaa, Juhani. The Thinking Hand (Architectural Design Primer). Chichester: John Wiley \& Sons, 2009.

Sikorska, Magdalena. „A Modern Master Looking Back: The Art of Sven Nordqvist”. What do you see? International Perspectives on Children's Book Illustration. Red. J. Harding, P. Pinsent. Newcastle upon Tyne: Cambridge Scholars Publishing, 2008. S. 52-63.

Wall, Barbara. The Narrator's Voice:The DilemmaofChildren's Fiction. Basingstoke:PalgraveMacmillan,1991.

Wideburg, Laura A. „Pettson and Findus charm children and adults alike”. World Literature Today 79 (2005). S. 71-72. 